\title{
ПРОБЛЕМА МОВИ У МОСКВОФІЛЬСЬКІЙ ПРЕСІ СХІДНОЇ ГАЛИЧИНИ (ПОЧ. ХХ ст.)
}

\author{
Тетяна Слотюк \\ Львівський національний університет імені Івана Франка \\ вул. Ген. Чупринки, 49, 79044, Львів, Україна \\ e-mail: burdeha@ukr.net \\ https://orcid.org/0000-0001-8883-4154
}

У статті досліджено проблему мови у пресі москвофільського руху, який вже від початку XX століття набирав антиукраїнського характеру. Особливу увагу звернено на актуальні концепти, які сьогодні активно використовує російська пропаганда. Поняття мови виноситься із площини комунікації у площину політичної доцільності та об’єднувального фактора із Росією.

Ключові слова: москвофільська преса, проблема мови, антиукраїнська політика.

Актуальність теми зумовлена глибоким сучасним підтекстом, який виявлений у таких засадничих ідеях російської пропаганди: основоположною запорукою триєдності «русского народа»є російська мова; присутність російської мови на комунікативній карті Східної Галичини означатиме присутність тут «русских»; заперечення існування української мови легалізує ідею про російську мову як загальнослов'янську та ін.

Мета дослідження - з'ясувати основні ідейно-тематичні детермінанти проблеми мови у пресі москвофільського руху у Східній Галичині на початку ХХ ст. Це передбачає вирішення таких завдань: розглянути ідейну зумовленість публікацій про мову у москвофільській пресі; проаналізувати вплив цих публікацій на суспільно-політичну думку у Східній Галичині; визначити особливості формування політичної складової мовної проблеми у москвофільській пресі на початку ХХ ст.

Результати й обговорення. Основне завдання москвофільської преси на початку XX ст. полягало в тому, щоб виконувати не стільки інформаційну й комунікаційну функцію, скільки - політичну стратегію, здійснювати ідеологічно-пропагандистське забезпечення інтересів Росії. Постає запитання: якими теоретичними й політичними детермінантами було позначене функціонування москвофільської преси? У статті «Русская идея в Галиции» Д. Донцов зазначав: «Теоретической основой партии [йдеться про москвофілів. - T. C.] является учение о «триединой Руси». Москвофилы думают, что русские, украинцы, белоруссы - один народ, что украинский язык - не язык, а жаргон и что литературным языком для украинцев должен быть русский» [2, с. 65].

(с) Слотюк Т., 2019 
Системна криза, що охопила москвофільський рух ще на початку 80 -х років XIX ст., стала особливо помітною наприкінці XIX ст. в контексті українського національного життя (хоча навіть тоді цей рух був його частиною). Ні в практичному, ні в теоретичному плані москвофільський рух не зміг протиставити галицьким українцям рівноцінні здобутки. На вихід у світ знаменної праці М. Міхновського «Самостійна Україна» (1900) москвофільський діяч та публіцист О. Мончаловський відповів брошурою «Живые вопросы», в якій обгрунтовував всеслов’янське значення російської мови і потребу її поширення в Австро-Угорщині, висміяв українську мову, ідею незалежної України назвав злочинною. Проголошення «Русско-народной партии» (1900) мало радше символічний характер і лише формально засвідчувало існування москвофільського руху як організованої політичної партії.

На поверхні політичного життя Східної Галичини москвофільський рух тримався завдяки двом зовнішнім чинникам: фінансовій підтримці з боку Росії та підтримці з боку польських «ендеків» Р. Дмовського, оскільки «народова демократія» провадила русофільську політику, а в Східній Галичині цій партії потрібен був союзник у боротьбі із щораз міцнішим українським визвольним рухом (слов'янський конгрес у Празі 1908 року мав теж антиукраїнське спрямування).

На з'їзді мужів довіри «Русско-народной партии» (1900) москвофільське керівництво ще раз повторило основні принципи, які сповідувала «Русско-народная партия»: національна і культурна єдність всього «русского народа»; необхідність для «русского населения» Австрії здобувати освіту і розвивати культуру, не розриваючи зв’язків із традиційними основами «русского народа» (а вони були відомі - «самодержавие, православие, народность»); партія вбачала своє завдання в тому, щоб захищати «русское население» Австрії від його національних противників (тобто від українців - «мазепинців» і «сепаратистів») і від вбивчого для «русской народности» та церкви соціалізму; беручи до уваги приналежність «русского населения» Галичини до «малорусского племени», керівництво партії визнавало природну необхідність займатися просвітою «русского населения» в Галичині «галицко-русским наречием», але не відмовляючись від «общерусского языка и общерусской литературы, представляющихъ национальное и культурное выражение всего русского народа» $[10$, c. 9].

У центрі політичної боротьби було мовне питання, з яким було пов'язана низка проблем: й інтерпретація минулого, і проблема окремішності українського народу, i відповідь на болісне для наддніпрянських українців (малоросів) і галицьких русинів від середини XIX ст. - питання ідентичності.

І в цьому ми вбачаємо зумовленість регулярної появи на сторінках москвофільської преси публікацій, в яких порушено мовну проблему. Проте це був не мовний, а суто політичний дискурс, який мав розв'язати через дискусію про мову політичні проблеми і досягти політичної мети. Варто звернути увагу на вибір мови у тому чи іншому москвофільському виданні: це або російська мова (в «Прикарпатской Руси», наприклад, цілком пристойна), або ж «російська» мова «Галичанина» (радше «огидний російсько-галицький волапюк», як висловився Ф. Корш про російсько-малоросійський суржик у містах України), або так звана «народна мова» «Русского слова» $\mathrm{i}$ «Голоса народа» та інших москвофільських видань 3 етимологічним правописом. Саме $з$ політичних міркувань москвофіли не вживали тієї української мови, якою послуговувалися українські видання. Для москвофілів не існувало української лі- 
тературної мови, українську мову вони вважали «наречием» російської мови. Використання української мови означало б їі визнання і заперечувало б, відповідно, ідею «единства русского народа». Постійна наявність у політичному контенті москвофільської преси публікацій з приводу мови, правопису, української літературної мови на початку XX ст. теж не була випадковою. Процес формування української літературної мови в XIX ст. був складним, він мав політичний підтекст. Йдеться про процес формування української нації, що не могла сформуватися на іншомовній основі.

Формування української літературної мови невіддільне від загального процесу становлення українців як нації. Воно було одним із виявів повноцінного суспільного буття, цей процес виходив за межі філологічної проблеми. Особливість мовної ситуації в Галичині дуже слушно схарактеризував Ю. Шевельов: «Вплив Галичини i ïi мови був одним 3 нових і до певної міри підривних процесів, що нуртували за фасадою позірної стабільности Російської імперії» [11, с. 37]. Це зрозуміли не стільки галицькі москвофіли, скільки їхні російські покровителі. Цим і треба пояснювати антиукраїнську спрямованість, активність багатьох російських учених, політиків, публіцистів, чиї публікації регулярно друкували в пресі москвофільського руху. Про суспільну вагомість мовної проблеми свідчить більшість публікацій на цю тему в «Галичанине» за 1900 р. Це праці, наприклад, проф. Київського університету Т. Флоринського «Об усвоению малорусскому языку роли органа науки и высшей образованности» («Галичанинъ» друкував упродовж 38 чисел (січень-березень) та А. Будиловича (ректора Юр'євського університету) «О литературномъ языке в Юго-Западной Руси» (опубліковано у десяти числах «Галичанина» в листопаді), це десятки інших публікацій, в яких іноді, навіть незалежно від предмета розмови, йшлося або про велич, силу й необхідність російської мови в житті слов'ян, або заперечувалася українська мова як така. Ідея «единой и неделимой Руси» - ось у чому суть державницького підходу Т. Флоринського, всі думки, твердження його праці підпорядковані саме цій ідеї. У різних варіантах їі тиражувала преса москвофільського руху і в наступні роки.

Директивний характер для ідеологічно-пропагандистської діяльності москвофілів мала і стаття А. Будиловича «О литературномъ языке в юго-западной Руси». Повний текст цієї праці вийшов окремою брошурою. У концептуальному плані праці Т. Флоринського і А. Будиловича ідентичні. Обидва вбачають у процесі формування української літературної мови насамперед політичний підтекст. Опублікування двох таких солідних праць (не стільки наукових, скільки публіцистичних, зважаючи на характер аргументації, стиль і мету), поданих частинами, забезпечувало перманентність комунікативного впливу, але не його ефективність.

Дискусія з приводу української мови була відображенням боротьби не лише за сучасне українського народу, а й за його історичні перспективи. Це помітно в роки першої російської революції, вибух якої був спричинений не лише соціальними, але й нерозв’язаними національними проблемами. Ці дискусії відновилися після відродження української преси у Наддніпрянській Україні. Однак, Д. Дорошенко зазначає, що національний рух у російській Україні зростав так швидко, що мова не встигала за ним, а коли на початку 1905 року почали виходити українські газети, то вже не було часу сперечатися про те, якою мовою писати, які слова вибирати: «Коли народжувалася нова українська преса, то, правду сказати, мало хто звертав увагу на 
те «якою мовою писати...» [4, с. 231]. Дискусія про мову тривала, бо ще вийшли друком дискусійні праці Б. Грінченка («Тяжким шляхом» в 1906 р.), I. Нечуя-Левицького («Криве дзеркало української мови» у 1911 р.).

Російська революція і український рух, що був потужним у Галичині і зростав у російській Україні, і зумовили увагу москвофільської преси до проблеми мови. Один iз пропагандистських піків мовного дискурсу припав на 1907 рік. Це пов’язано $з$ парламентськими виборами. Маніпулюючи поняттями «русский язык», «язык галицко-русских», «общерусский литературный язык», «Галичанинъ» прагне домогтися запровадження «русского официального языка» в громадському діловодстві (№ 60), регулярно з'являються антиукраїнські публікації. Найбільш одіозні, що були опубліковані до парламентських виборів, поєднувалися з публікаціями (власними або передруками з російських газет), в яких повторювалася одна і та ж теза - «единство русского народа».

Публікації з політичним підтекстом радикально налаштованих москвофілів, які фактично утверджували повну ідентичність із «русским народом» і «общерусский язык» як загальноосновну мову спілкування, певною мірою дисонували з позицією політичного товариства «Русская Рада», керівництво якої заявило у своєму заклику: «Кто презираетъ языкъ своих предковъ яко «мертвеччину» и прозывает его «язычиемъ», тот подобен выродному сыну, осквернившему могилу своих родителей» [3].

Поява в 1907 р. ще кількох ідеологічно чітко означених публікацій, передрук статей відомого київського українофоба Т. Флоринського мали підготувати аудиторію до головної політичної події року - виступу в парламенті російською мовою москвофільського посла Д. Маркова, що відбувся 26 червня (9 липня) 1907 року. «Галичанинъ» назвав цей день історичним для Карпатської Русі. Безперечно, що це не була особиста ініціатива Д. Маркова. В одному із наступних чисел «Галичанинъ» заявив про початок боротьби за права «русского языка» в Австрії, закликав збирати підписи (як у 1892 р. проти запровадження фонетичного правопису) для підтримки Д. Маркова. У цій ситуації йшлося не про історичну обгрунтованість присутності «русского народа» в Галичині, а про досягнення певної політичної мети. Джерелом цієї інформації був не Д. Марков, а Російська імперія як суб’єкт міжнародного права. Москвофільська преса чи її публіцисти тільки здійснювали процес комунікації (ми використовуємо схему, яку запропонував Г. Почепцов) [6, с. 120]. А отримувачем, адресатом інформації був не лише «русский народ» Галичини. Ще більшою мірою ця інформація була призначена для міжнародної громадськості, для урядів європейських країн, зокрема, й для Відня, який мав усвідомити, що Галичина - це «исконно русская земля», на якій живе «русский народ» («Галичанинъ», москвофільські публіцисти навіть перестали вживати означення «галицко-русские»).

Подальші події (з’їзд мужів довіри «Русско-народной партии», потужна пропагандистська позиція проти «рутенства», не менш активна антиукраїнська кампанія, регулярна поява публікацій про «общерусский язык» в Австрії) явно свідчили про політизацію (з проросійською орієнтацією) інформаційно-комунікаційного процесу. Після з’їзду мужів довіри «Галичанинъ» уже відверто (на відміну від попередніх років) пише про «общерусский язык» в Австрії як реальний факт. Політизація інформаційно-комунікаційного процесу, яка полягала в утвердженні російської мови й ідентичності, в ідеологічно-пропагандистському забезпеченні європейського i, зокрема, галицького вектора політики Росії, зміцнювалася із наближенням слов'ян- 
ського конгресу в Празі. Одним із його завдань була нейтралізація українського руху і заперечення окремішності українського народу.

«Галичанинъ» передрукував у кількох числах із «Киевлянина» знакову для «Киевского клуба русских националистов» статтю «Украинский язык» (№ 174-176 за 1908 р.). Як відомо, 37 депутатів Думи внесли законопроект про запровадження викладання українською мовою в народних школах малоросійських губерній. Автор вважає, що цей законопроект суперечить як здоровим історичним і політичним поглядам, так і справжній користі населення південно-російських губерній. Створення («ковка») нових штучних літературних мов - самовбивче для народного духу. «Украинский язык», на думку автора, штучно створили впродовж останніх десятиріч галицькі українофіли на чолі з М. Грушевським, а засвоєння громадськістю цієї мови значно важче, ніж «общерусского языка», бо це не мова, а жаргон. Автор зауважує, що «законопроект 37» переслідує не педагогічні, а винятково політичні цілі українофілів - створення політично незалежної України.

Надії москвофілів на слов’янський з'їзд у Празі (1908), який повинен був спричинитися до російсько-польського порозуміння і взаємних поступок (поляки підтримують «русских» у Галичині, а російський уряд йде назустріч полякам у Росіі) не справдилися. «Галичанинъ» не приховував свого розчарування з приводу виступу P. Дмовського, лідера «вшехполяків» у газеті «Słowo Polskie», який заявив, що поляки не можуть мати симпатій до спроб штучного перетворення русинів у «русских». Hi стриманість польських партій щодо визнання «русского народа» в Галичині, ні поміркований виступ М. Короля в Галицькому сеймі (квітень 1908 року), який теж заперечив спроби «новокурсників» ідентифікувати галицьких русинів як «русских» - ніщо не могло стримати інформаційно-пропагандистську кампанію.

Обидва москвофільські угруповання продовжили антиукраїнську пропаганду і після розколу, хоча певна відмінність у комунікаційній тактиці і стратегії була. Не маючи симпатій ні до українців («мазепинців» і «сепаратистів»), ні до української мови, заперечуючи потреби заснування українського університету, старше покоління і надалі прагнуло залишатися «старорусинами», «галицко-русскими», лояльними до Відня. «Галичанинъ» у 1912 році заявляв: «Культурное и национальное единство всех русских племен - это главная, принципиальная основа русско-народного движения в Австрии» [5]. Натомість «новокурсники» («Русская народная организация»), позиціонуючи себе як «русских» і домагаючись офіційного визнання та відповідних прав, зафіксованих у Конституції Австро-Угорщини, утверджували себе як проросійська політична сила, як виконавець російського політичного проекту щодо Галичини. Після розколу «Русско-народная партия» поступово занепадає як активна політична сила. Керівництво партії визнавало, що вона мало займалася народними масами, мало спілкувалася 3 ними. Така самооцінка дає підстави зробити висновок про низьку ефективність комунікативного процесу москвофільської преси («старорусинів»), але причини глибші, ніж ті, які зазначали «старорусини». Проросійська політична позиція, яку зайняли «новокурсники» («Русская народная организация»), полягала у цілковитому запереченні української ідеї (i різних її аспектів: мови, ідентичності, культури, літератури), що більше, «Русская народная организация» поділяла погляди російського націоналістичного руху. Ї̈̈ друкований орган («Прикарпатская Русь») виходив російською мовою, оскільки був призначений для інтелігенції. Широка аудиторія російської мови не знала, тому ефективність комунікаційного 
зв’язку між комунікатором і адресатом не могла бути високою. Зрештою, й до інтелігенції газета зверталася російською мовою, якої не знала, але вибір мови був зумовлений політичними міркуваннями. Це щонайменше мало означати у такій формі присутність Росії, легітимізувати її можливі претензії на Галичину як на «исконно русские земли», населення (інтелігенція) якої розмовляє на «русском языке».

У вересні 1909 року у Києві відбувся з’їзд російських націоналістів (взяли в ньому участь і москвофіли-»новокурсники» з Галичини), на якому обговорювали i «русский вопрос» у Галичині й Буковині. З’їзд ухвалив захищати «русский элемент в провинциях искони русских» (№ 16 «Прикарпатской Руси» за 1909 р.), так вважали і в РНО. Визнання «русской (russisch) народности в Австрии - это вопрос жизни и смерти народности!» [7]. I партія, і їі друковані органи («Прикарпатская Русь», «Голосъ народа») вимагали цього визнання без участі народу.

Анексія Боснії та Герцеговини (1908), Слов’янський з’їзд у Празі (1908) загострили суперечності між Росією і Австро-Угорщиною. У ще один чинник зростання міжнародного конфлікту щораз більше перетворювалася Галичина, якій російський уряд (за допомогою громадських організацій і «благодійних» товариств, а також проросійської «Русской народной организации») намагався створити імідж «исконно русской земли» 3 «русским народом». У цьому й виявилася головна функція РНО. Виконуючи їі, намагаючись нав'язати галицьким русинам (а багато хто 3 них уже відчував себе українцем) думку про те, що вони «русские», «Прикарпатская Русь» боролася не так із рутенством («опаснейшим злом национального сознания»), як 3 українською ідеєю, а українське питання напередодні Першої світової війни перетворилося у важливу міжнародну проблему. У разі воєнного конфлікту Галичина опинялася в центрі подій. Саме тому російські урядові й праві (націоналістичні) кола почали активно і цілеспрямовано підтримувати «Русскую народную организацию» і фінансово забезпечувати пропагандистську кампанію, яку вона провадила. Зовсім не випадково 1909 року вийшла друком «Грамматика русского литературного (общерусского) языка для русских в Галичине, Буковине, Угрии» С. Бендасюка. 3'явилася вона після відомого виступу Д. Маркова російською мовою в австрійському парламенті. Підручник починався зверненням «Дорогіи братья, русские крестьяне и мЂщане!». Як і Б. Дідицький, С. Бендасюк стверджував, що «русский литературный различается отъ нашего галицко-русского наречия (говора) единственно немногими меньше понятными словами и иным выговором где-яких букв» [1, с. 5]. Суть в іншому. С. Бендасюк зазначає про політичне значення появи підручника, про політичні наслідки вивчення і поширення російської мови: «Прежде всего съ поры, якъ нашъ народъ усвоить себъ тот языкъ, то украинский сепаратизм упаде у нас быстро самъ собою безъ боротьбы, без спороิвъ» [1, с. 8]. Новий виток пропагандистської кампанії розпочався 1911 р. Це було зумовлено переписом населення. РНО вимагала, щоб населення записувало себе як «русский» (з двома «с»).

Як програмну «Прикарпатская Русь» сприйняла статтю П. Струве «Общеруская литература и украинский партикуляризм» в «Русской мысли» (№ 5 за 1911 р.) і зреферувала 11ї у № 397 за 1911 р. П. Струве замінив гострий за політичним змістом термін «сепаратизм» на «партикуляризм», але це суттєво не вплинуло на його основні тези. Він заперечував ідею української самостійності й доводив, що нема української культури як такої; заперечував окремішність українського народу (відповідно і мови), критикував тих, хто ставив в один ряд етнографічні терміни «великорусс- 
кий», «малорусский», «общерусский», замовчуючи, що $є$ ще термін «русский», (це було повторення тієї ж давньої ідеї «триединства русского народа»). П. Струве був проти відкриття середніх та вищих шкіл з українською мовою і необхідності розвивати українську культуру. Усі ці твердження мали явний політичний підтекст і преса РНО використовувала їх у комунікаційному процесі. Ф. Корш (відомий російський філолог, академік) на сторінках «Украинской жизни» (№ 2 за 1912 р.) спростував основні тези П. Струве у статті «К спору об украинской культуре».

РНО ж вбачала у формуванні української літературної мови (як і російські українофоби) небезпеку для ідеї «единства русского народа», сприймала його як перешкоду у формуванні «русской» ментальності «галицко-русских», тобто українців. Зокрема, 1911 р. галицький намісник видав циркуляр щодо мови викладання в москвофільських бурсах. Там самовільно ігнорували українську мову і запроваджували російську, відповідно комплектувалися і бібліотеки у бурсах, влаштовувалися заходи для вшанування російських письменників, тобто вихованцям намагалися нав’язати чуже їм відчуття «русскости». Цей циркуляр викликав протест РНО та іï преси. «Прикарпатская Русь» намагалася пояснити, принижуючи українську літературу і мову, чому в бурсах викладають «общерусский литературный язык». Питання бурс і мови викладання було ніби частковим, але воно цілком узгоджувалося із загальною політичною стратегією РНО.

Висновки. 3 огляду на це постає питання: що $є$ головним і визначальним у природі преси, оскільки у функціонуванні преси повинен бути сенс - політичний, економічний? Оскільки регулярно виходили лише партійні друковані органи (головно завдяки фінансовій допомозі з боку Росії), то очевидним $є$ той факт, що про економічну ефективність цієї преси мови не може бути. Отже, залишається з'ясувати політичний сенс функціонування москвофільської преси. С. С. (сільський дописувач газети «Русская Рада», найбільш поміркованої серед москвофільської преси того часу) зауважував у дописі «О хлопскихъ газетахъ», що їх погано редагують, що «они кормлять хлопа исключно лишь политикою и творять що раз то нови партіи» [8], що більше треба висвітлювати справи громадські і господарські. Політизація комунікаційного процесу не сприяла ні ефективності впливу москвофільської преси, ні суспільній взаємодії. Москвофільська преса неодноразово заявляла про критичний стан свого руху, про невдачі в політичній та економічній сфері життєдіяльності. «Прикарпатская Русь» зазначала: «...после стольких чувствительных поражений нашей партии, которых главной виновницей и была наша злополучная печать, мы нуждаемся в газете, которая перевоспитала бы нас, возродила...» [9].

Визнання москвофільських лідерів і публіцистів про невдачі, поразки свого руху, про неефективність преси не було риторичним, воно відображало реальний стан речей. Але вже на початку 90-х років XIX ст. було зрозуміло, що москвофіли програли боротьбу за народ, у порівнянні з українським визвольним рухом. Не ефективність впливу на соціум була головним завданням москвофільської преси. Сенс існування москвофільського руху та його преси був в іншому. Російська мова газет і журналів, виступи російською мовою в парламенті чи сеймі, «Русский день» у Львові (від 1906 р.), боротьба за православ’я і визнання «общерусского языка» як мови «русского народа» в Галичині, існування (навіть і формальне) різноманітних москвофільських товариств і організацій, безкомпромісна і фанатична боротьба 3 українською ідеєю - усе це мало демонструвати присутність фантомного «русского 
народа», щоб у вигідній ситуації Росія мала підстави висловити Австро-Угорщині територіальні претензії щодо визволення «исконно русских земель» і «русского народа».

\section{REFERENCES}

1. Бендасюк С. Грамматика русского литературного (общерусского) языка для русских в Галичине, Буковине, Угрии / С. Бендасюк. Львов, 1909. 376 с.

2. Донцов Д. «Русская идея» в Галиции / Д. Донцов // Украинская жизнь. 1912. С. $64-74$.

3. Къ галицко-русскому народу / [Без автора] // Галичанинъ. 1907. № 124.

4. Матеріали з історії національної журналістики Східної України початку XX століття / [уклад. Н. М. Сидоренко, О. І. Сидоренко]. К. : Дослід. центр історії укр. преси, 2002. 448 с.

5. Петрушевич А. С. Ruthenen или Russen? / А. Петрушевич // Галичанинъ. 1912. № 180.

6. Почепцов Г. Г. Коммуникативные технологии двадцатого века / Г. Г. Почепцов. М. : «Рефл-бук»; К. : «Ваклер», 1999. 352 с.

7. Русскій. Досужіе мысли / [Без автора] // Прикарпатская Русь. 1909. № 18.

8. С. С. О хлопскихъ газетахъ / С. С. // Русская Рада. 1912. № 10.

9. Столбинъ. Всеобщий орган и всеобщее въ немъ сотрудничество / Столбинъ // Прикарпатская Русь. 1909. № 6.

10. Съезд мужей доверия Русско-народной партии и ее организаций. Львов : Изд. политич. о-ва «Русская Рада» во Львове, 1900. 41 с.

11. Шевельов Ю. Українська мова в першій половині двадцятого століття (1900-1914): Стан і статус / Ю. Шевельов. Мюнхен : Сучасність, 1970. 295 с. 


\title{
PROBLEM OF LANGUAGE IN THE RUSSOPHILE PRESS OF THE EASTERN GALICIA (THE BEG. OF XX CENT.)
}

\author{
Tetiana Slotiuk \\ Ivan Franko National University of Lviv \\ Gen. Chuprynky street, 49, 79044, Lviv, Ukraine \\ e-mail:burdeha@ukr.net \\ https://orcid.org/0000-0001-8883-4154
}

The article deals with the problem of language in the press of the Russophile movement, which has been gaining anti-Ukrainian character since the beginning of the 20th century. Particular attention is paid to the actual concepts that are currently actively used by Russian propaganda. The notion of language moves from the plane of communication to the plane of political expediency and the unifying factor with Russia. The purpose of the article is to find out the main ideological and thematic determinants of the language problem in the press of the Russophile movement in Eastern Galicia at the beg. of the XX cent. The task of this work is to point out the structural key points that actualize this problem; to study the features of the presentation of the speech topic in the Russophile press; to highlight the journalistic discourse around this topic of those who did not perceive the ideas of Russophile movement. Research methods - problematic and thematic method applied at all stages of the study; the historical method of research gives us an opportunity to show the historical precondition of the publications and works of the ideologues of the Muscophile movement and their opponents on the language problem; bibliographic-descriptive method used at the stage of the choice of editions that we studied in the context of studying the language problem; comparative-analytical test for the study of the ideological and conceptual foundations of the Russophile press, which concerned language problems.

The problem of this research has a deep modern undertone, because attention is paid to such fundamental ideas, which today are actively cultivated by Russian propaganda, that today are actively cultivated by Russian propaganda - the basic guarantee of the «russian people» trinity is the Russian language; the presence of the Russian language on the communicative map of Eastern Galicia will mean the presence of «Russians» here; the denial of the Ukrainian language existence legalizes the idea of the Russian language as a general Slavic, and others.

Key words: Russophile press, language problem, anti-Ukrainian politics. 